\title{
The Uncoupling Protein 2 Ala55val Polymorphism is Associated with Diabetes Mellitus in a Balinese Population
}

\author{
Made Ratna Saraswati ${ }^{*}$, Ketut Suastika1 ${ }^{1}$, Safarina G. Malik², Herawati Sudoyo² \\ ${ }^{1}$ Endocrinology and Metabolism Division, Department of Internal Medicine, Faculty of Medicine Udayana University / Sanglah Hospital \\ ${ }^{2}$ Eijkman Institute for Molecular Biology, Jl. Diponegoro 69, Jakarta, Indonesia
}

\begin{abstract}
Background. The activity of uncoupling proteins have been reported to be associated with obesity and energy metabolism, and it is hypothesized that sequence variation in this gene might contribute to the pathogenesis of type 2 diabetes mellitus.

Objective. To investigate the association of the UCP2 Ala55Val polymorphism with blood glucose level and anthropometric status.

Methods. In a cross sectional study, 287 participants (179 male; 108 female) from Legian Village, Kuta, Bali, were enrolled. The UCP2 Ala55Val (C544T) polymorphism was detected by PCR-RFLP method. Fasting and 2 hours postprandial blood glucose were measured. Anthropometric status including body mass index (BMI) and waist circumference were taken. Analysis of variance (ANOVA) was used to test the equality of continuous variables. To compare categorical variables, a chi-square test was employed.
\end{abstract}

Results. The genotype frequency of the C/C (Ala/Ala), C/T (Ala/Val), and T/T (Val/Val) are 44.9\%, 45.6\%, and 9.4\%, respectively. The minor allele frequency of the $\mathrm{T}(\mathrm{Val})$ allele is $32 \%$. Individuals with the $\mathrm{T} / \mathrm{T}$ (Val/Val) genotype have higher incidence of diabetes mellitus than those with the C/C (Ala/Ala) or C/T (Ala/Val) genotypes: $18.5 \%, 7.03 \%$, and $6.92 \%$, respectively $(p=0.038)$. No significant associations were observed between Ala55Val polymorphism and obesity based on BMl and waist circumference determination.

Conclusion. The UCP2 Ala55Val polymorphism was associated with diabetes mellitus in a Balinese population of Legian Village, Kuta, Bali. No significant association was observed between Ala55Val polymorphism and obesity.

Keywords: UCP2Ala55Val, diabetes mellitus, obesity

\section{Introduction}

The investigation of heritable susceptibility to disease is an effort to associate disease phenotype with underlying genotype. Significant technological advances for identification of single-nucleotide polymorphisms (SNPs) have further strengthened research methodologies for genetic analysis. Association studies are the most widely used for identifying susceptibility gene(s) to advances in understanding the pathophysiology of disease. The simplest sort of association study count the frequency of each allele at a polymorphic marker and association exists when the allele frequencies differ between subject with disease and subject without disease. ${ }^{1}$
Uncoupling proteins (UCPs) are mitochondrial transporters present in the inner membrane of mitochondria. They are found in all mammals and in plants. They belong to the family of anion mitochondrial carriers including adenine nucleotide transporters. Uncoupling proteins (UCPs) reduce adenosine triphosphate (ATP) generation by separating oxidative phosphorylation from ATP production, and the energy is released as heat. The protein carrier catalyzes the regulated movement of protons across the mitochondrial inner membrane in brown adipose tissue, generating heat, and is therefore called UCP. The term "uncoupling protein," was originally used for UCP1 that resides on chromosome 4q31, which is uniquely present in mitochondria of brown adipocytes, the thermogenic cells 
that maintain body temperature in small rodents. UCP2, ubiquitous and highly expressed in the lymphoid system, macrophages, and pancreatic islets, was discovered in 1997. However, definitive understanding of its function has so far eluded investigators. Potential role include regulating fat metabolism directly and indirectly via effects on insulin secretion. UCP3 is mainly expressed in skeletal muscles. The activities of UCPs have been reported to be associated with obesity and energy metabolism. In comparison to the established uncoupling and thermogenic activities, UCP1, UCP2, and UCP3 appear to be involved in the limitation of free radical levels in cells rather than in physiological uncoupling and thermogenesis. Moreover, UCP2 is a regulator of insulin secretion and UCP3 is involved in fatty acid metabolism. UCP2 and UCP3 were both mapped to chromosome 11q13 in humans. ${ }^{2-4}$

The mitochondrial uncoupling protein-2 (UCP-2) has been proposed to be involved in the regulation of energy balance. Several reports have shown that deficiency of UCP-2 gene expression has been observed in obesity, a disorder that is associated with disturbed energy homeostasis. ${ }^{5-7}$ UCP2 was reported to be associated with childhood-onset obesity in African American, Asian, and Caucasian children. ${ }^{8}$

The onset of type 2 diabetes mellitus is preceded by obesity, insulin resistance, and impaired beta-cell function. UCP2 is expressed in a wide range of tissues including pancreatic cells, and several recent findings emphasize the hypothesis that sequence variation in this gene might contribute to the pathogenesis of type 2 diabetes mellitus. Work in transgenic mice suggests that increased expression of UCP2 decreases glucose-stimulated insulin secretion, thus impairs glucose homeostasis and increases the risk of diabetes mellitus. ${ }^{9}$ Support for the hypothesis that UCP2 is a negative regulator of insulin secretion comes from investigations using UCP2 -/- mice that showed increased circulating insulin concentrations concomitant with reduced blood glucose in the fed state. ${ }^{10}$

In this study, we investigated the frequency of the homozygote C/C (Ala/Ala), heterozygote C/T (Ala/Val), and homozygote $\mathrm{T} / \mathrm{T}$ ( Val/Val). We also looked for the association of the commonly observed UCP2 Ala55Val polymorphism with blood glucose level and anthropometric status.

\section{Subjects and Methods}

A cross sectional study was conducted in Legian Village, Kuta, Bali. Subjects (aged 18 years old or more) were recruited from this village by stratified random sampling, and 287 (179 males, 108 females) participants were enrolled with informed consent (with the approval of the Faculty of Medicine Ethic Committee, Udayana University, and the Eijkman Institute Research Ethics Commission). Fasting and 2 hour - postprandial blood glucose were measured. Anthropometric status, included height, weight, and waist circumference (WC). Body mass index (BMI) was calculated as weight in $\mathrm{kg}$ divided by (height) ${ }^{2}$ in $\mathrm{m}^{2}$. Classification of weight by BMI and abdominal obesity by WC are determined according to the Asia-Pacific perspective redefining obesity in adult Asians. ${ }^{11}$ BMI classification was as follows: underweight (< $\left.18.5 \mathrm{~kg} / \mathrm{m}^{2}\right)$, normal $\left(18.5-22.9 \mathrm{~kg} / \mathrm{m}^{2}\right)$, overweight at risk (BMI 23-24.9 kg/m²), obese I (BMI 25-29.9 kg/m²), and obese II (BMI $\left.\geq 30 \mathrm{~kg} / \mathrm{m}^{2}\right)$, while the criteria for abdominal obesity were $\mathrm{WC} \geq 90 \mathrm{~cm}$ in male and $\mathrm{WC} \geq 80 \mathrm{~cm}$ in female.

DNA samples for genomic DNA analysis were isolated from Guthrie Cards using Chelex-100 protocol, as previously described. ${ }^{12}$ The UCP2 Ala55Val (C164T) polymorphism was detected by PCR-RFLP (polymerase chain reaction-restriction fragment length polymorphism) method, as described previously. ${ }^{13}$ Briefly, a 198 bp fragment of UCP2 exon 4 was PCR amplified using a pair of primer, 5'-CTGGAGTCTCGATGGTGTCTAC3'(forward)and5'-CACCGCGGTACTGGGCGTTG-3' (reverse). This primer pair possessed mismatch bases to introduce a HincII site, which is used to digest the PCR fragment. The digested product was then separated on 3\% agarose gel electrophoresis. The $\mathrm{Val} / \mathrm{Val}$ genotype was detected by the presence of HincII site, resulting in $179 \mathrm{bp}$ and $19 \mathrm{bp}$ fragments.

The equality of continuous variables was tested by using the analysis of variance (ANOVA). Comparison of categorical variables was examined by employing the chisquare test.

\section{Results and Discussion}

Of the 287 participants enrolled, the mean age was found to be $46.6 \pm 9.9$ (range: $20-83$ ) years. Three genotypes of UCP2 Ala55Val were found in the population of Legian Village, Kuta, Bali: Ala/Ala (C/C), Ala/Val (C/T), and $\mathrm{Val} / \mathrm{Val}(\mathrm{T} / \mathrm{T})$. The representative of the PCR-RFLP results are shown in Fig. 1A. Genotype frequency of the homozygote C/C (Ala/Ala), heterozygote C/T (Ala/Val), and homozygote T/T (Val/Val) are 44.9\% (129/287), 45.6\% (131/287), and 9.4\% (27/287), respectively (Fig. 1B). Allele frequency of the C (Ala) allele in this population is $68 \%$, whereas the $\mathrm{T}$ (Val) allele is $32 \%$ (Fig. 1C).

The characteristics of the study subjects based on the genotypes of UCP2 Ala55Val are summarized in Table 1. The mean BMI, waist circumference, fasting blood glucose, and 2 hour - postprandial blood glucose are $25.8 \pm 4.9,88.5$ $\pm 10.7,98.1 \pm 36.7,109.8 \pm 56.1$, respectively.

Indication of higher fasting and 2 hour - postprandial blood glucose were observed in $\mathrm{T} / \mathrm{T}(\mathrm{Val} / \mathrm{Val})$ genotype, as compared with the $\mathrm{C} / \mathrm{T}$ (Ala/Val) or $\mathrm{C} / \mathrm{C}$ (Ala/Ala) genotypes $(103.0 \mathrm{mg} / \mathrm{dL}, 98.1 \mathrm{mg} / \mathrm{dL}$, and $97.1 \mathrm{mg} / \mathrm{dL}$ for fasting blood glucose; $115.9 \mathrm{mg} / \mathrm{dL}, 109.5 \mathrm{mg} / \mathrm{dL}$, 
$108.9 \mathrm{mg} / \mathrm{dL}$ for 2 hour - postprandial) (Table 1). However, the differences between these genotypes were not significant (Fig. 2).

We then determined type 2 diabetes mellitus based on the levels of fasting and 2 hour - postprandial blood glucose. Individuals with $\mathrm{BMI}>25 \mathrm{~kg} / \mathrm{m}^{2}$ were considered obese, while male with $W C \geq 90 \mathrm{~cm}$ or female with $W C \geq 80 \mathrm{~cm}$ were included in the abdominal obesity group. We found that those with the $\mathrm{T} / \mathrm{T}(\mathrm{Val} / \mathrm{Val})$ genotype have a higher incidence of diabetes mellitus than those with the $\mathrm{C} / \mathrm{C}$ (Ala/Ala) or C/T (Ala/Val) genotypes: $18.51 \%, 7.03 \%$, and $6.92 \%$, respectively $(p=0.038)$ (Table 2$)$. No significant associations were observed between Ala55Val polymorphism and obesity based on BMI or abdominal obesity based on WC determination (Table 2).

We have studied the association of UCP2 Ala55Val polymorphism with diabetes mellitus in the population of Legian Village, Kuta, Bali. Legian Village is a famous tourist destination in Bali. Being a tourist destination, this village has many hotels and restaurants serving local and western food, including fast food restaurants. Although the price of this western food is usually higher than local food, it has become familiar since tourism improves the economic lives of the people. This population has been chosen based on several considerations : first, they have been exposed to Westernization for more than two decades, and second, increased incidence of diabetes mellitus and obesity has been observed. Therefore this particular population would be a good model for an association study of genetic variation and disease. Association of the commonly observed UCP2 Ala55Val polymorphism with diabetes mellitus and impaired fasting glucose (IFG) among 3684 participants in the Coronary Artery Risk Development in Young Adults (CARDIA) study has been reported. ${ }^{14}$ In this study the $\mathrm{Val} / \mathrm{Val}(\mathrm{VV})$ genotype had a higher incidence of diabetes than those having the Ala/Ala (AA) genotype (5.8\% vs $3.3 \%$; $p=0.02) .{ }^{14}$, which is in line with our result $(18.51 \%$ in $\mathrm{Val} / \mathrm{Val}$ genotype vs $7.03 \%$ in Ala/Ala genotype vs $p=0.038$ ).

The effects of UCP2 variants, including the Ala55Val, on BMI and T2DM, as well as on insulin secretion in relation to family-specific factors, have been confirmed in various studies which include a case-control population study, a family-based association study, and a metabolic study of

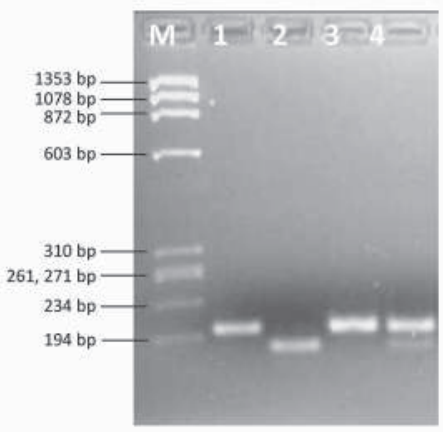

A

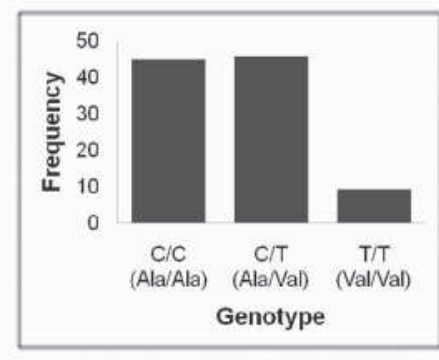

B

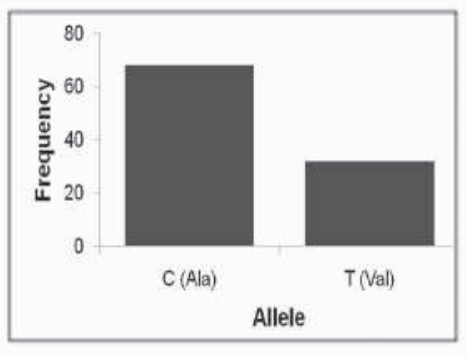

C

Figure 1. UCP2 Ala55Val detection and frequency. A. UCP2 Ala55Val (C164T) polymorphism was detected by PCRRFLP method. ${ }^{12}$ The digested fragments were electrophoresed in a $3 \%$ agarose gel at 80 Volt for 1.5 hours, and visualized under UV light. M: DNA marker ( $\phi$ X174 RF/HaellI), lane 1: PCR fragment (uncut DNA), lane 2: Val55 homozygote, lane 3: Ala55Val heterozygotes, lane 4: Ala55 homozygote. B. Genotype frequencies of C/C (Ala/Ala; 44.9\%), C/T (Ala/Val; 45.6\%), and T/T (Val/Val; 9.4\%). C. Frequency of major C (Ala; 68\%) and minor T (Val; 32\%) alleles.
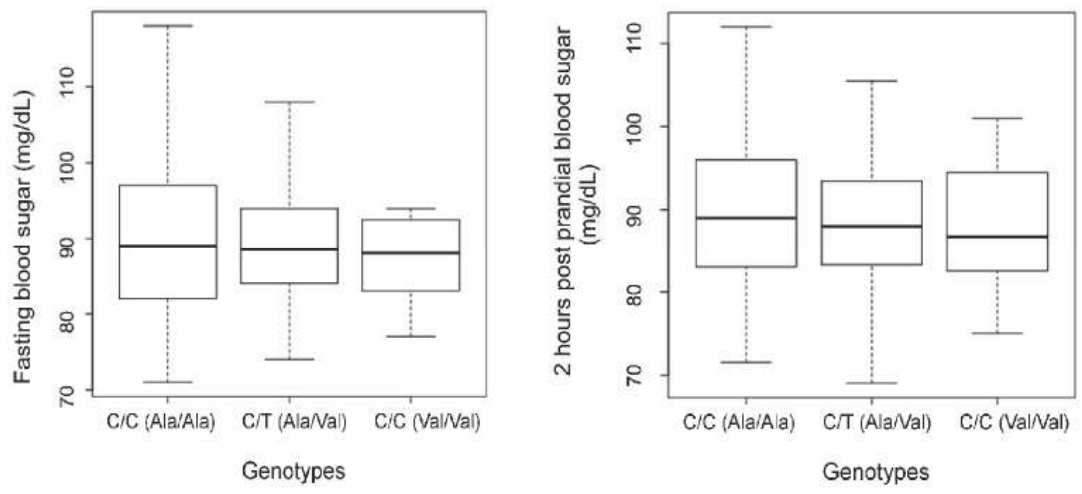

Figure 2. Distribution of fasting and 2 hour - postprandial blood glucose levels based on genotypes of UCP2 Ala55Val. Fasting ( left panel) and 2 hour postprandial (right panel) blood glucose levels were plotted against genotypes. The 25 and 75 percentile coverage is indicated by the boxes, while the error bars indicate 10 and 90 percentile points. The horizontal line within the box is the median. 
Table 1. Characteristics of study subjects grouped by UCP2 Ala55Val genotype

\begin{tabular}{|c|c|c|c|c|}
\hline & C/C (Ala/Ala) & $\mathrm{C} / \mathrm{T}$ (Ala/Val) & $\mathrm{T} / \mathrm{T}$ (Val/Val) & Total \\
\hline$n=287$ & $n=129$ & $n=131$ & $n=27$ & \\
\hline Male : female (\%) & $61: 39$ & $66: 34$ & $52: 48$ & $62: 38$ \\
\hline Age & $45.0 \pm 9.9$ & $46.2 \pm 9.5$ & $50.2 \pm 11.6$ & $46.0 \pm 9.9$ \\
\hline Body weight $(\mathrm{kg})$ & $66.3 \pm 13.5$ & $70.0 \pm 13.6$ & $66.3 \pm 11.9$ & $68.0 \pm 13.5$ \\
\hline Height $(\mathrm{cm})$ & $162.0 \pm 8.6$ & $162.4 \pm 10.9$ & $162.1 \pm 7.7$ & $162.2 \pm 9.7$ \\
\hline BMI $\left(\mathrm{kg} / \mathrm{m}^{2}\right)$ & $25.1 \pm 4.1$ & $26.7 \pm 5.6$ & $25.1 \pm 3.8$ & $25.8 \pm 4.9$ \\
\hline$W C(\mathrm{~cm})$ & $87.1 \pm 10.3$ & $90.1 \pm 11.0$ & $87.9 \pm 10.4$ & $88.5 \pm 10.7$ \\
\hline $\mathrm{FBS}(\mathrm{mg} / \mathrm{dL})$ & $97.1 \pm 29.5$ & $98.1 \pm 40.9$ & $103.0 \pm 46.3$ & $98.1 \pm 36.7$ \\
\hline 2 h PPBS (mg/dL) & $108.9 \pm 42.1$ & $109.5 \pm 64.2$ & $115.9 \pm 73.9$ & $109.8 \pm 56.1$ \\
\hline
\end{tabular}

postprandial blood glucose level

\begin{tabular}{|c|c|c|c|c|c|}
\hline & C/C (Ala/Ala) & $\mathrm{C} / \mathrm{T}$ (Ala/Val) & $\mathrm{T} / \mathrm{T}$ (Val/Val) & Total & $p$ \\
\hline $\begin{array}{l}\text { Diabetes mellitus, n (\%) } \\
\text { Obesity, n (\%) }\end{array}$ & $\begin{array}{l}9(7.03) \\
88(68.21)\end{array}$ & $\begin{array}{l}9(6.92), \\
103(79.2)\end{array}$ & $\begin{array}{l}5(18.51) \\
19(70.3)\end{array}$ & $\begin{array}{l}23(8.07) \\
210(73.42)\end{array}$ & $\begin{array}{l}0.038^{*} \\
0.124\end{array}$ \\
\hline Abdominal obesity, n (\%) & $75(58.13)$ & $84(65.11)$ & $15(55.55)$ & $174(61.05)$ & 0.428 \\
\hline
\end{tabular}

and $W C \geq 80 \mathrm{~cm}$ in female. ${ }^{11}$ * Statistically significant, $B M I=$ body mass index, $W C=$ waist circumference

individuals whose insulin sensitivity and secretory patterns were reported. ${ }^{9}$ In a Taiwan community UCP2 Ala55Val variant was reported to be associated with obesity and also with increased insulin concentration that may lead to insulin resistance. ${ }^{15}$ However, although the prevalence of obesity (73.42\%) and abdominal obesity $(61.03 \%)$ were found to be high in this study, no association was observed between the UCP2 Ala55Val polymorphism and obesity (high BMI) or abdominal obesity (high WC).

There are many risk factors that have been reported to be associated with obesity, and genetic variations are among them. Therefore, it is possible that the high prevalence of obesity and abdominal obesity observed in the population of Legian village, Kuta, was associated with other genetic factors, such as the beta adrenergic receptor (ADRB) gene polymorphisms. Further study is needed to explore the possibility of the involvement of genetic variations as risk factor for obesity in this population.

\section{Conclusion}

The UCP2 Ala55Val polymorphism was associated with diabetes in the population of Legian village, Kuta, Bali. However, there was no significant association observed between Ala55Val polymorphism and obesity based on BMI or abdominal obesity based on WC determination.

\footnotetext{
Acknowledgement

This study has been conducted as a collaborative study group between the Internal Medicine Department Udayana University/Sanglah Hospital - Denpasar Bali, and the Eijkman Institute for Molecular Biology, Jl. Diponegoro, Jakarta, Indonesia. Clinical data was taken in Denpasar and the genetic analysis was done in Jakarta. The authors gratefully acknowledge the participation of many volunteers. We would like to thank both the Udayana University/Sanglah Hospital group (N Dwi Sutanegara,
}

AAG Budhiarta, Wira Gotera, Pande Dwipayana, Anwar Santoso, Ketut Rina, Ketut Badjranadha, IGN Gunadhi, Ketut Suwitra, Raka Widiana, Wayan Sudhana, Jodi Sidharta L, Yenny Kandarini, GA Arini Junita, IGP Arsana, Abdul Halim, Tjok Istri Anom Saturti, and Surya Sanjaya Funistera), and the Eijkman Institute for Molecular Biology group (Sukma Oktavianthi, Hidayat Trimarsanto, Ni Luh Made Agustini Leonita, and Agung Budiman).

\section{References}

1. Rosmond R. Association studies of genetic polymorphisms in central obesity: a critical review. Int J Obes Relat Metab Disord. 2003; 27:1141-1151.

2. Rousset S, Alves-Guerra MC, Mozo J, Miroux B, AM CassardDoulcier, Bouillaud F, et al. The biology of mitochondrial uncoupling proteins. Diabetes. 2004; 53(Suppl.1):S130-135.

3. Brand MD, Esteves TC. Physiological functions of the mitochondrial uncoupling proteins UCP2 and UCP3. Cell Metab. 2005; 2:85-93.

4. Argyropoulos G, Harper ME. Molecular biology of thermoregulation, Invited review: Uncoupling proteins and thermoregulation. J Appl Physiol. 2002; 92:2187-2198.

5. Dulloo AG, Seydoux J, Jacquet J. Adaptive thermogenesis and uncoupling proteins: a reappraisal of their roles in fat metabolism and energy balance. Physiol Behav. 2004; 83:587-602.

6. Oberkofler H, Liu YM, Esterbauer H, Hell E, Krempler F, Patsch W. Uncoupling protein-2 gene: reduced mRNA expression in intraperitoneal adipose tissue of obese humans. Diabetologia. 1998; 41:940-6.

7. Schonfeld-Warden NA, Warden CH. Physiological effects of variants in human uncoupling proteins: UCP2 influences body-mass index. Biochem Soc Trans. 2001; 29:777-84.

8. Yanovski JA, Diament AL, Sovik KN, Nguyen TT, Li H, Sebring NG, et al. Associations between uncoupling protein 2, body composition, and resting energy expenditure in lean and obese African American, white, and Asian children.. Am J Clin Nutr. 2000; 71:1405-12.

9. Wang H, Chu WS, Lu T, Hasstedt SJ, Kern PA, Elbein SC. Uncoupling protein-2 polymorphisms in type 2 diabetes, obesity, and insulin secretion. Am J Physiol Endocrinol Metab. 2004; 286:E1-7.

10. Saleh MC, Wheeler MB, Chan CB. Uncoupling protein-2: evidence for its function as a metabolic regulator. Diabetologia. 2002; 45:174-87.

11. WHO Regional Office for the Western Pacific: The Asia-Pacific perspective: redefining obesity and its treatment. Manila, Philippines: World Health Organization; 2000.

12. Bereczky S, Martensson A, Gil JP, Farnert A. Short report: rapid DNA extraction from archive blood spots on filter paper for genotyping of Plasmodium falciparum. Am J Trop Med Hyg. 2005; 72(3): 249-251. 
13. Kubota T, Mori H, Tamori $\mathrm{Y}$, Okazawa H, Fukuda T, Miki M, et al. Molecular screening of uncoupling protein 2 gene in patients with noninsulin-dependent diabetes mellitus or obesity. J Clin Endocrinol Metab. 1998; 83:2800-2804.

14. Yu X, Jacobs Jr. DR, Schreiner PJ, Gross MD, Steffes MW, Fornage M. The Uncoupling Protein 2 Ala55Val Polymorphism Is Associated with Diabetes Mellitus: The CARDIA Study. Clin Chem. 2005; 51:1451-1456.

15. Wang TN, Huang MC, Lin HL, Hsiang CH, Ko AM, Chang WT, et al. UCP2 A55V variant is associated with obesity and related phenotypes in an aboriginal community in Taiwan. Obes. 2007; 31:1746-1752.

16. Kagawa Y, Yanagisawa Y, Hasegawa K, Suzuki H, Yasuda K, Kudo $\mathrm{H}$, et al. Single nucleotide polymorphisms of thrifty genes for energy metabolism: evolutionary origins and prospects for intervention to prevent obesity-related diseases. Biochem Biophys Res Commun. $2002 ; 295: 207-222$

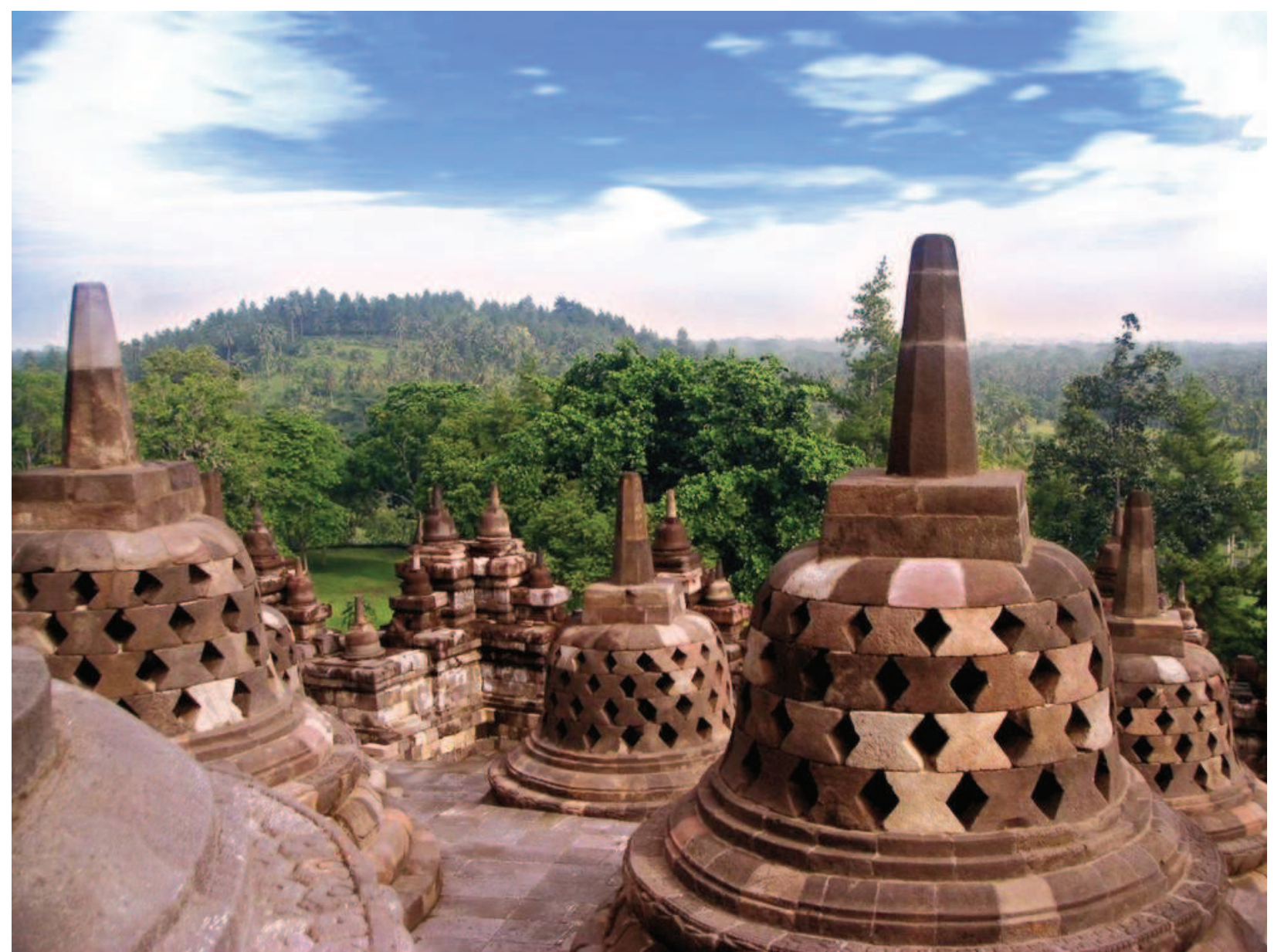

Borobodur, the great Buddhist stupa, stands in sacred tranquility at Kedu Plain, in Java, Indonesia. Photograph courtesy of Dr. Dyah Purnamasari. 